\title{
ANTIOXIDANT AND ANTIMICROBIAL ACTIVITIES OF ALgERIAN POPULUS NIGRA L. BUDS EXTRACTS
}

\author{
DJAMILA MERGHACHE ${ }^{\mathrm{A}^{*}}$, ZAHIA BOUCHERIT-OTMANI $^{\mathrm{A}}$, IMAD El HACI ${ }^{\mathrm{B}, \mathrm{F}}$, SALIMA \\ MERGHACHE $^{\mathrm{C}}$, ILYAS CHIKHI ${ }^{\mathrm{D}}$, AND KEBIR BOUCHERIT ${ }^{\mathrm{A}, \mathrm{E}}$ \\ a Antibiotics, Antifungal: Physical Chemistry, Synthesis and Biological Activity \\ Laboratory, Department of Biology, Faculty of Natural sciences and life sciences and \\ earth and the universe. University of Tlemcen, P. O. Box 119, Tlemcen 13000, Algeria. \\ ${ }^{\mathbf{b}}$ Laboratoire des Produits Naturels (LAPRONA), University of Tlemcen, Algeria; \\ ${ }^{c}$ Laboratoiry of inorganic chemical and environnement (LCIE) University of Tlemcen, \\ Algeria; \\ ${ }^{\mathrm{d}}$ Laboratory of Natural and Bioactive substances (LASNABIO), University of Tlemcen, \\ Algeria. \\ ${ }^{\mathrm{e}}$ University center of Ain Tmouchent, Algeria, 46000, Algeria. \\ ${ }^{\mathrm{f}}$ Centre de Recherche Scientifique et Technique en Analyses Physico - Chimiques \\ C.R.A.P.C \\ BP 384, Zone Industrielle Bou-Ismail RP 42004 Tipaza, Algeria
}

\begin{abstract}
This study is part of a goal to investigate chemical composition, antibacterial, antifungal and antioxidant activities of the flower buds extracts from the Algerian Polulus nigra L., which were collected from Djarifet - mansourah at Tlemcen city in the West Northern of Algeria.

In organic extracts, tanins, flavonö̈ds, coumarins, alkaloids and terpenö̈ds were the principals secondary metabolites identified from the flower buds of black poplar. Antibacterial and antifungal activities of extracts were tested using agar-well diffusion method and micro-well determination of MIC assay against eleven bacteria and two Candida species. It was found that extracts of black poplar buds exhibit antibacterial and anticandidal activities with agar disk diffusion (7 to 43mm) and MIC methods (MIC= $90.33 \mu \mathrm{g} / \mathrm{ml}$ against several strains of bacteria and MIC=45.16 $\mu \mathrm{g} / \mathrm{ml}$ against Candida albicans). The antioxidant effect of hydroalcoholic extract was evaluated using DPPH and FRAP assays. It was showed good and similar activity than ascorbic acid and BHA by DPPH method: $I C_{50}=220 \mu \mathrm{g} / \mathrm{mL}$ for hydroethanol extract.
\end{abstract}

\section{KEYWORDS:}

Populus nigra L. extracts, Antibacterial and antifungal activities, DPPH antioxidant power, Ferric reducing antioxidant power assay (FRAP).

\section{INTRODUCTION:}

Medicinal plants are a very important natural resource whose valuation requires a perfect knowledge of the properties to develop. The medicinal activities of herbal depend on the presence of various bioactive agents belonging to different chemical classes (Ouraïni et al., 2005).

In many African and Asian countries, herbal medicine continues to be widely used. All these figures show that people are turning back to traditional medicine and medicinal plants mainly to (Muthu et al., 2006). 
In Algeria, the empirical use of plants continues to maintain a high popularity [(Benmerabet and Abed, 1982) ; (Boulos, 1983)]. The Algerian people are sometimes preying of quackery ignorant and dangerous for patients. Many plants are known for their therapeutic properties, especially for their antiseptic, antibacterial and antioxidant effect, as Rosemary, Sage, Thyme, Garlic, Anise, Chamomile, Eucalyptus, Grenadier, mild Orange, etc ... (Ali-Delille, 2013).

For this, the use of medicinal plants with biological properties is one of the most interesting research areas to explore. Our work is based in this perspective is to determine the chemical composition of extracts of black poplar buds (Populus nigra) in the first time and secondly to highlight their antibacterial and antioxidant activities. This species is a member of Salicaceae family (family with 350 species), Greek"People", Latin for" to stir: tree leaves trembling. Flowering occurs in April and May. This tree, that can live up to 150 years, is very demanding in water and light, it is present in almost all of Europe and Northern Africa, especially the Northern Algerian, and more exactly, Elkala, Kabylie and Tlemcen [(Belouad, 200) ; (Ali-Delille, 2010)].

\section{EXPERIMENTAL}

Black poplar buds were collected in March - April 2010 from Dzarifet in Tlemcen, the West Northern of Algeria (GPS coordinates: $34^{\circ} 53^{\prime} 24^{\prime \prime} \mathrm{N} 1^{\circ} 19^{\prime} 12^{\prime \prime} \mathrm{W}$ ). The plant was botanically identified by Mr. Yebedri (forestry engineer) and a voucher specimen of the plant was deposited in the Herbarium of the Laboratory of Botany, Department of Biology, Tlemcen University, Algeria. Before extraction, the buds can be dried away from the light.

\subsection{Extracts \\ 2.1.1. Preparation of extracts}

Ten grams of the pulverized materials were extracted by maceration with $100 \mathrm{ml}$ of solvent (hexane, chloroform, methanol and water) and subjected to continuous agitation at $200 \mathrm{rpm}$ for 24 hours, at room temperature $\left(25-28^{\circ} \mathrm{C}\right)$. The solution thus obtained is filtered, using filter paper (Whatman $\mathrm{n}^{\circ} 4$ ). The filtrate was evaporated in a rotary evaporator, until the extracts became completely dry and were totally dissolved in dimethylsulphoxide (DMSO) and stored in a labelled, sterile screw-capped bottle at $+4 \circ \mathrm{C}$ until use.

\subsubsection{Chemical study}

This study helps to show up the main chemical groups present in the plant in a qualitative way. The ground spice was tested for térpenoïdes, alkaloids and phenolic compounds (tannins, anthocyanes, flavonoids, coumarins, quinones). phytochemical study is performed according to the protocols of Dohou and al. (2003), Karumi and al. (2004) Oloyede (2005) and Edeoga (2005).

\subsection{Antibacterial and antifungal activities 2.2.1. Microbial strains}

Antimicrobial activities of $P$. nigra extracts were tested against 11 strains of bacteria: Grampositive bacteria: Staphylococcus aureus (ATCC 25923), Bacillus cereus (ATCC 10876), Enterococcus faecalis (ATCC 49452), Listeria monocytogenes (ATCC 15313), Gram-negative bacteria: Pseudomonas aeruginosa (ATCC 27853), Escherichia coli (ATCC 25922), Salmonella typhimurium (ATCC 13311), Acinetobacter baumanii (ATCC 19606), Citrobacter freundii (ATCC 8090), Proteus mirabilis (ATCC 35659), Klebsiella pneumoniae (ATCC 700603) and 2 yeasts : Candida albicans (ATCC 26790), Candida albicans (ATCC 10231). Strains tested cultures are maintained in their proper slants at $4^{\circ} \mathrm{C}$. 
Bioscience \& Engineering: An International Journal (BIOEJ), Vol.3, No.1/2, April 2016

\subsubsection{Screening for antibacterial and antifungal activities:}

The disk diffusion method was used to determine antimicrobial activity of the $P$. nigra buds extracts (Espinel-Ingroff, 2007). Briefly, the recommended medium is sterile Mueller Hinton agar (MHA) supplemented with glucose and methylene blue for yeasts and MHA for bacteria strains. The Petri plates containing the MHA was incubated by swabbing with the microbial suspension $\left(1 \times 10^{6}\right.$ cells $\left./ \mathrm{mL}\right)$, using sterile cotton-tipped swabs, and powered into Petri dishes to give a solid plate. Ten microliters of extracts dissolved in DMSO were applied on sterile paper discs $(6 \mathrm{~mm}$ in diameter, Whatman $\mathrm{n}^{\circ} 1$ ). The discs were deposited on the surface of incubated agar plates. Plates were kept for 15minits to enable prediffusion of the substances into the agar and then incubated at $35^{\circ} \mathrm{C}$ and $37^{\circ} \mathrm{C}$ for 24 hours, for yeasts and bacteria respectively. The diameters of the inhibition zones were measured in millimeters. All the tests were performed in triplicate.

\subsubsection{Micro-well determination (CMI)}

Inocula of the microorganisms were prepared from $18 \mathrm{~h}$. Cultures and the suspensions were adjusted to $10^{8} \mathrm{CFU} / \mathrm{mL}$ of bacteria or $10^{6} \mathrm{CFU} / \mathrm{mL}$ of yeasts with different concentrations of crude extracts (table 3 ). This test was repeated in triplicate. Gentamicin, ketoconazole and amphotericin B were used as reference antimicrobials. The antibacterial and antifungal activities of DMSO were tested for each microorganism (Sokmen et al. 2004).

\subsection{Antioxidant activity 2.3.1. Quantification of total phenolic contents}

Total phenolic contents of ethanolic extract were determined using Folin-Ciocalteu reagent using

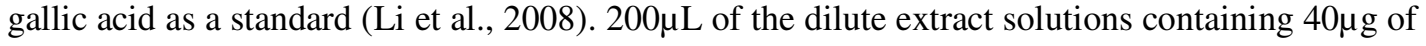
the hydroalcoholic were added to $1 \mathrm{~mL}$ of Folin-Ciocalteu reagent (diluted in distillated water). After $4 \mathrm{~min}, 800 \mu \mathrm{L}$ of $\mathrm{Na}(75 \mathrm{mg} / \mathrm{mL})$ solution was added and the mixture was allowed to stand for $45 \mathrm{~min}$ at room temperature. After incubation, the absorbance was measured at $760 \mathrm{~nm}$ with a spectrophotometer (Optizen POP spectrophotometer). The same procedure was also applied to the gallic acid solution and a standard curve was obtained. The concentrations of phenolic compounds expressed as mg gallic acid equivalent per $\mathrm{g}(\mathrm{mgGAE} / \mathrm{g})$ of extract were calculated according to the standard gallic acid graph. All experiments were carried out in triplicate.

\subsubsection{Determination of total flavonoids contents}

Total flavonoid contents of the hydroalcoholic buds extract of $P$. nigra were determined using the Dowd method as adapted by Arvouet-Grand et al., (1994). One milliliter of $2 \%$ aluminium trichloride $\left(\mathrm{AlCl}_{3}\right)$ in methanol was mixed with $200 \mu \mathrm{g}$ of extract. After $10 \mathrm{~min}$ of incubation, absorption was measured at $430 \mathrm{~nm}$ against a blank sample $\left(1 \mathrm{~mL}\right.$ ofmethanol without $\mathrm{AlCl}_{3}$ ). The concentrations of flavonoid compounds expressed as $\mathrm{mg}$ of catechin equivalent per $\mathrm{g}(\mathrm{mg} \mathrm{CE} / \mathrm{g}$ ) of extract were calculated according to the standard catechin graph. All experiments were carried out in triplicate.

\subsubsection{DPPH radical scavenging assay}

The diluted hydroalcoholic solutions $(5,10,25,50,75,100,250,500,750$ and $1000 \mu \mathrm{g} / \mathrm{mL})$ were prepared in ethanol. An ethanolic DPPH solution $(24 \mu \mathrm{g} / \mathrm{mL})$ was freshly prepared and $2 \mathrm{~mL}$ of this solution was added to $50 \mu \mathrm{L}$ of hydroalcoholic solutions in ethanol at different concentrations. After $30 \mathrm{~min}$ of incubation, the absorbance was measured at $517 \mathrm{~nm}$ using a spectrophotometer (UV/VIS Spectrophotometer OPTIZEN POP). The blank of $2 \mathrm{~mL}$ of DPPH 
solution with $50 \mu \mathrm{L}$ of ethanol was used. The reduction of DPPH solution absorbance indicates an increase in DPPH radical scavenging activity (\% of inhibition), using following equation:

$\%$ DPPH radical scavenging $=\left[\left(\mathrm{A}_{0}-\mathrm{A}\right) / \mathrm{A}_{0}\right] \times 100$

$\mathrm{A}_{0:}$ : Absorbance of blank;

A: Absorbance of tested sample solution at $30 \mathrm{~min}$.

The same procedure was followed for the positive control: ascorbic acid and tert-butyl-4hydroxyanisole (BHA). The ethanol was used for baseline correction.

\subsubsection{Ferric reducing antioxidant power assay (FRAP)}

Various concentrations of hydroalcoholic $(5,10,25,50,75,100,250,500,750$ and $1000 \mu \mathrm{g} / \mathrm{mL})$ in distilled water were mixed with phosphate buffer $(2.5 \mathrm{ml}, 0.2 \mathrm{M}, \mathrm{pH} 6.6)$ and $1 \%(\mathrm{w} / \mathrm{v})$ of potassium ferricyanide water solution $(2.5 \mathrm{~mL})$. The mixture was incubated at $50^{\circ} \mathrm{C}$ for $20 \mathrm{~min}$. Aliquots of trichloracetic acid $(2.5 \mathrm{~mL}, 10 \%$, aqueous solution $(\mathrm{w} / \mathrm{v}))$ were added to the mixture which was then centrifuged at $3000 \mathrm{rpm}$ for $10 \mathrm{~min}$. The supernatant $(2.5 \mathrm{~mL})$ was mixed with distilled water $(2.5 \mathrm{ml})$ and a freshly prepared ferric chloride solution $(0.5 \mathrm{~mL}, 0.1 \%(\mathrm{w} / \mathrm{v})$. After $30 \mathrm{~min}$ of incubation at room temperature in the dark, the absorbance of the resulting solution was measured at 700nm using a spectrophotometer (UV/VIS Spectrophotometer OPTIZEN POP) (Oyaizu, 1986). Ascorbic acid and BHA were used as positive control. The results were expressed graphically by plotting absorbance against concentration.

\section{RESULTS}

The phytochemical screening of the flower buds of $P$. nigra specie has shown the absence of quinones, anthocyanes and saponosids. However, these buds, among other sterol substances, flavonoids, tannins, terpenoids and alkaloids, these substances have been identified as antimicrobial and / or antioxidant products. The results of this study show that black poplar buds are a major source of polyphenols, alkaloids and terpenes compounds.

These secondary metabolites can be an excellent herbal alternative. Undeniable authors have shown that the salicaceaes family contains various aromatic compounds such as caffeic acid, isofelurique, p-coumaric, salicin, salicylic acid, salicortin, the salicin alcohol, the salicyloylsalicine, aromatic ketones, free fatty acids, organic acids, 4-ethylphenol, terpenoids, catechol, the flavanone (eriodictyol, pinocembrin and pinostrobine), the isoflavones (chrysin, apigenin), flavonols (galangin, kaemphérol , quercetin, rutin, quercetin 3-methyl ether) as majority compounds. In addition, more than 160 types of compounds have been isolated from species of the genus Populus, the majority are triterpene esters, sterols, flavonoids, alkaloids, lactones, lignans and resins [(Bankova et al., 1989); (Greenaway and Whatley, 1991); (Morreel et al., 2006); (Dudonné et al., 2011)]. The results of our phytochemical extracts of $P$. nigra buds study, going in the same direction.

A study was conducted by Isidorov and Vinogorova in 2003 on the chemical composition of the hexane and ether extract of $P$. nigra and $P$. balsamifera buds. The extracts were obtained by selective extractions and analyzed by GC / MS. The results exhibit the presence of volatile compounds, with 50 and 51 compounds for the hexane and ether extracts respectively. These various aromatic moieties are hydrocarbon sesquiterpenes, sesquiterpenoids, cinnamic acid, aromatic compounds $\left(\mathrm{C}_{6}-\mathrm{C}_{10}\right)$, aliphatic acids, and phenolic carboxylic acids, flavonoids, ect …

Table 1 showed that extracts present a good antimicrobial activity ( 7 to $43 \mathrm{~mm}$ ) against tested strains. The maximum zone of inhibition were obtained with chloroform extract recorded $E$. faecalis $(36 \mathrm{~mm})$, and aqueous extracts against $C$. albicans ATCC $10231(43 \mathrm{~mm})$. The in vitro 
Bioscience \& Engineering: An International Journal (BIOEJ), Vol.3, No.1/2, April 2016

antibacterial and antifungal activities of $P$. nigra buds extracts were evaluated in the second time by the minimum inhibitory concentration (MIC) test against some pathogenic bacteria and yeasts (Table 2). The important MICs of extracts were observed against C. albicans ATCC 10231 $(45.1 \mu \mathrm{g} / \mathrm{mL})$ and $E$. faecalis $(74.2 \mu \mathrm{g} / \mathrm{mL})$, with aqueous and chloroform extracts respectively.

Table 1. Antibacterial and antifungal activities of P. nigra buds extracts from the West Northern of Algeria.

\begin{tabular}{|l|l|l|l|l|}
\hline Extract & Hexan & Chloroform & Methanol & Water \\
\hline Concentration $(\mathbf{m g} / \mathbf{m L})$ & $\mathbf{1 0 6 . 1 2}$ & $\mathbf{1 5 2 . 0 5}$ & $\mathbf{4 0 3 . 3 1}$ & $\mathbf{1 8 5}$ \\
\hline S. aureus ATCC 25923 & 12 & 18 & 17 & 14 \\
\hline B. cereus ATCC 10876 & 10 & 12 & 12 & 08 \\
\hline E. faecalis ATCC 49452 & 13 & 36 & 20 & 18 \\
\hline L. monocytogenes ATCC 15313 & 10 & 18 & 12 & 12 \\
\hline P. aeruginosa ATCC 27853 & $/$ & 7 & 8 & 9 \\
\hline E. coli ATCC 25922 & 10 & 25 & 12 & 14 \\
\hline S. typhimurium ATCC 13311 & 7 & 8 & 8 & 8 \\
\hline A. baumanii ATCC 19606 & 10 & 9 & 8 & 12 \\
\hline C. freundii ATCC 8090 & $/$ & $/$ & $/$ & $/$ \\
\hline$P$ mirabilis ATCC 35659 & 18 & 22 & 17 & 23 \\
\hline K. pneumoniae ATCC 700603 & 16 & 16 & 15 & 10 \\
\hline C. albicans ATCC 26790 & 13 & 15 & 14 & 26 \\
\hline C. albicans ATCC10231 & 16 & 15 & 17 & 43 \\
\hline
\end{tabular}

n.a: not active

Table 2. MIC $(\mu \mathrm{g} / \mathrm{mL})$ of P. nigra buds extracts from the West Northern of Algeria against human pathogenic bacteria and yeast strains.

\begin{tabular}{|l|l|c|c|c|c|c|c|}
\hline Microorganisms & Hex & Chrm & MeOH & Water & Gnt & AmB & Ktzl \\
\hline S. aureus ATCC 25923 & 829.0 & 296.9 & 295.4 & 361.3 & 10.0 & - & - \\
\hline B. cereus ATCC 10876) & 1243.0 & 296.9 & 590.8 & 1083.9 & 10.0 & - & - \\
\hline E. faecalis ATCC 49452) & 829.0 & 74.2 & 147.7 & 361.3 & 10.0 & - & - \\
\hline L. monocytogenes (ATCC 15313) & 1243.6 & 296.9 & 590.8 & 361.3 & 5.0 & - & - \\
\hline P. aeruginosa (ATCC 27853) & $/$ & 593.9 & 1181.5 & 1083.9 & 15.0 & - & - \\
\hline E. coli (ATCC 25922) & 1243.0 & 148.5 & 590.8 & 361.3 & 15.0 & - & - \\
\hline S. typhimurium (ATCC 13311) & 1658.1 & 593.9 & 1181.5 & 1083.9 & 20.0 & - & - \\
\hline A. baumanii ATCC 19606) & 1243.6 & 593.9 & 1181.5 & 361.3 & 10.0 & - & - \\
\hline C. freundii (ATCC 8090), & $/$ & $/$ & $/$ & $/$ & 15.0 & - & - \\
\hline P. mirabilis (ATCC 35659), & 414.5 & 148.5 & 295.4 & 90,3 & 20.0 & - & - \\
\hline K. pneumoniae (ATCC 700603) & 414.5 & 296.9 & 295.4 & 1083.9 & 15.0 & - & - \\
\hline C. albicans (ATCC 26790) & 829.0 & 296.9 & 590.8 & 90.3 & - & 1.0 & 25.0 \\
\hline C. albicans (ATCC10231) & 414.5 & 296.9 & 295.4 & 45.1 & - & 1.0 & 25.0 \\
\hline
\end{tabular}

The antimicrobial activity of $P$. nigra extracts might be related to secondary metabolites present in buds. The Gram (+) bacteria were more sensitive to these extracts. This suggestion has been confirmed in previous studies. Smith-Palmer et al. (1998), Marino et al. (1999) and Inouye et al. (2001) have shown that Gram positive bacteria are generally more sensitive to plants extracts than Gram negative.

Chao et al. (2000) explained that Gram negative bacteria are equipped with peptidoglycan layer disposed between the plasma membrane and an external base consisting of lipopolysaccharides 
and proteins. This structure can prevent the extracts penetration or protect the peptidoglycan layer against antimicrobial compounds. The lipopolysaccharides (LPS) of Gram negative bacteria provides a barrier to inhibit the permeability of hydrophobic substances like essential oils, which may come and prevent the growth of Gram positive bacteria (Chao et al., 2000).

During our literature search, we found that some studies were interested in evaluating biological activities of naturally propolis from several species of the genus Populus. The study of Jug et al (2014) performed on the evaluation of the antimicrobial activity of extracts from several samples of propolis obtained from Populus, has shown that alcoholic and aqueous extracts were strongly inhibited growth of $S$. mutans, B. ceureus, P. aeruginosa and C. albicans. The results we have obtained are relatively in the same direction.

The amounts of total phenolics and flavonoids from hydroethanolic extract were determined spectrometrically according to the Folin-Ciocalteu and the method with aluminum chloride $\left(\mathrm{AlCl}_{3}\right)$ respectively. The extract of $P$. nigra buds presents high polyphenol $(674.66 \mathrm{mg} \mathrm{GAE} / \mathrm{g})$ and flavonoids (162.5 $\mathrm{mg} \mathrm{CE} / \mathrm{g})$ contents.

Antioxidant properties of hydroalcoholic extract were evaluated to find a new natural source of antioxidant. The results obtained at different concentrations $(5,10,25,50,75,100,250,500,750$ and $1000 \mu \mathrm{g} / \mathrm{mL}$ ) are shown in Figure1 and Figure2.

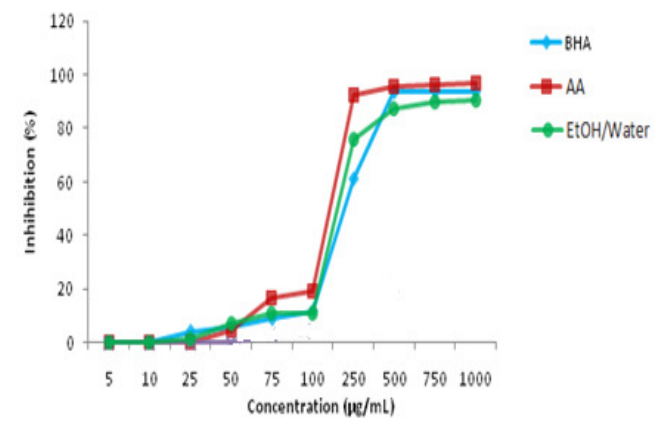

Figure1. DPPH radical-scavenging of hydroethanolic extract from $P$. nigra

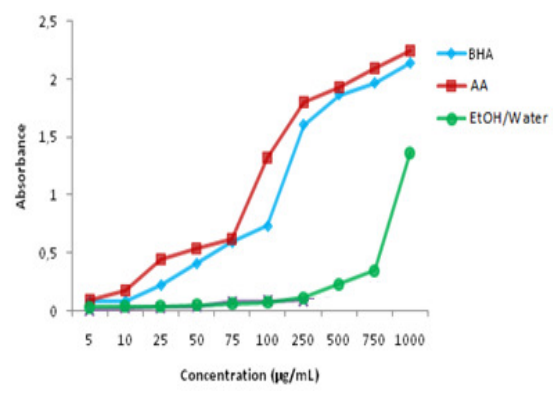

Figure 2. Ferric reducing antioxidant power assay (FRAP) of hydroethanolic extract from P. nigra at different concentrations.

The best percentages of antioxidant activities were observed for the synthetic antioxidants AA, hydroethanolic extract from P. nigra buds BHA and (96.56, 93.62 and 90.53\%, respectively), at a concentration of $1 \mathrm{mg} / \mathrm{mL}$.

The antioxidant capacity of hydroethanolic extract was determined by calculating the $\mathrm{IC}_{50}$ (Table 3 ). It presents the extract concentration required to reduce $50 \%$ of DPPH radical. It is inversely proportional to the percentage of scavenging free radical DPPH.

Table 3. Antioxidative activity expressed as IC50 values for DPPH scavenging activity of hydroethanolic extract of $P$. nigra buds.

\begin{tabular}{|l|l|l|l|}
\hline \multirow{2}{*}{ P. nigra } & IC $_{\mathbf{5 0}}(\boldsymbol{\mu g} / \mathbf{m})$ & \multicolumn{2}{|l|}{} \\
\cline { 2 - 4 } & EtOH/Water & BHA & AA \\
\hline
\end{tabular}


The $\mathrm{IC}_{50}$ results show that hydroalcoholic extract of $P$. nigra have a strong reducing effect on the radical DPPH $(\mathrm{IC} 50=220 \mu \mathrm{g} / \mathrm{mL})$. This value is comparable to those of the BHA $(230 \mu \mathrm{g} / \mathrm{mL})$ and ascorbic acid $(210 \mu \mathrm{g} / \mathrm{mL})$.

The results of the antioxidant activity by the FRAP method show that the hydroalcoholic extract of $P$. nigra has the ability to reduce the iron. To a final concentration of $1 \mathrm{mg} / \mathrm{mL}$, an optical density of 0.7235 was measured for this extract. This activity remains relatively lower than that obtained with AA and the BHA which have optical density of 2.2476 and 2.1361 respectively at the same concentration.

The Evaluation of antioxidant activity of $P$. nigra buds showed that hydroalcoholic extract exerts a trapping of the free radical DPPH power comparable to that obtained with the reference antioxidants (BHA and ascorbic acid). In addition, the colorimetric analysis revealed high levels of phenolic compounds in hydroalcoholic extract of this species. This activity depends on the chemical composition of this extract.

These results contradict those found by Dudonné and al (2011). These authors have conducted a study on the phenolic composition of the black poplar buds aqueous extract and its antioxidant activity by Oxygen Radical Absorbance Capacity method (ORAC). The results have showed that the aqueous extract contains an important phenolic content and has a moderate antioxidant activity. The main identified phenolic compounds are the phenolic acid and flavonoid aglycones (Dudonné et al., 2011).

Another study carried out on the rates of polyphenols and the evaluation of antioxidant activity of propolis extracts from black poplar. The results thus obtained have showed that propolis contain variable contents of polyphenols and flavonoids with maximum $353,9 \mathrm{mg} / \mathrm{g}$ and $123,3 \mathrm{mg} / \mathrm{g}$ respectively (Jug, et al., 2014). In addition, these same samples exert remarkable antioxidant activities by the three methods tested (FRAP, DPPH and Beta carotène- linoleic acid). $\mathrm{IC}_{50}$ obtained from DPPH method were ranging from 29 to $114,4 \mu \mathrm{g} / \mathrm{mL}$, depending on samples of propolis.

The study of Debbache et al.(2014) on the evaluation of the anti-inflammatory, antimicrobial and determining the rate of phenolic compounds from black poplar buds from Eastern region of Algeria, has shown that that extract obtained after two successive extractions with water and chloroform, has good trapping ability of the free radical DPPH with an $\mathrm{IC}_{50}$ of $187,90 \mu \mathrm{g} / \mathrm{mL}$.

\section{Conclusion}

The results suggest that extracts from the buds of $P$. nigra of Algeria could be a source of secondary metabolites, especially polyphenol and volatile compounds which present an important health promoting compound. Our studies have showed that hydroethanolic extract of black poplar buds exerts good antioxidant activity similar than BHA and ascorbic acid activity.

Our results also indicated that aqueous extract has a good antifungal activity in vitro. These results could support the use of this specie by traditional healers to treat several diseases. 


\section{REFERENCE}

1. Ali-Delille L. 2013. Les plantes médicinales d'Algérie. BERTI Edition, Alger, Algeria.

2. Arvouet-Grand A, Vennat B, Pourrat A, Legret P, 1994. Standardisation d'un extrait de propolis et identification des principaux constituants. J. de Pharma. De Belgique. 49: 462-468.

3. Bankova VS, Popov SS, Marekov NL .1989. nil cinnamates from poplar buds and Isopente-propolis. Phytochemistry 28, 871-873.

4. Belouad A. 2001. Plantes médicinales d'Algérie. Office des Publications Universitaires, Alger, Algérie.

5. Boulos L. 1983. Medicinal plants of North Africa. Ed Reference Publications Inc Michigan.

6. Ouraïni D, Agoumi A, Ismaili -Alaoui M, Alaoui K, Cherrah Y, Amrani M, Belabbas M-A. 2005. Study of the activity of essential oils from aromatic plants antifungal properties in the different stages of development of dermatophytes ; Phytotherapy; 4: 147-157

7. Chao S C, Young D G and Oberg G J. 2000. Screening for Inhibitory Actvity of Essential Oils on Selected Bacteria, Fungi and Viruses. J. Essent. Oil Res. 12 : 639-649.

8. Debbache N, Atmani D and Atmani D. 2014. Chemical analysis and biological activities of Populus nigra, flower buds extracts as source of propolis in Algeria, Industrial Crops and Products, 53, 85-92.

9. Dohou N, Yamani K, Tahrouch S, et al. 2003. Screeninig phytochimique d'une endémique ibéromarocaine, Thymelaea lythroides. Bull Soc Pharm Bordeaux 142: 61-78.

10. Dudonné S., Poupard P., Coutière P., Woillez M., Richard T., Mérillon J.-M., and Vitrac X. (2011) Phenolic Composition and Antioxidant Properties of Poplar Bud (Populus nigra) Extract: Individual Antioxidant Contribution of Phenolics and Transcriptional Effect on Skin Agings. J. Agric. Food Chem., 59 (9), 4527-4536.

11. Edeoga H O, Okwu D E, Mbaebie B O .2005. Phytochemical constitients of some Nigerian medicinal plants. Afr J Bioltechnol 4: 685-8.

12. Espinel-Ingroff A. 2007. Standardized disk diffusion method for yeasts with the National Committee for Clinical and Laboratory Standardsinstitute (CLSI formerly NCCLS) M44-A reference method for testing Candida spp. Clin Microbiol New 29(13): 97-100.

13. Greenaway W, and Whatley F R. 1991. Synthesis of ester acetyloxycaffeic acids and their occurrence in poplar bud exudates. J. Chromatogr. 543, 113-121.

14. Inouye S, Takizwa T and Yamaguchi H. 2001. Antibacterial Activity of Essential oils and Their Major Constituents Against Respiratory Tract Pathogens by Gaseous Contact. J. Antimi. Chemo. 47: 565-573

15. Isidorov V A and Vinogorova V T. 2003. GC-MS Analysis of Compounds Extracted from Buds of Populus balsamifera and Populus nigra; Z. Naturforsch. 58c, 355-360.

16. Jug M, Zovko Konci M and Kosalec I. 2014. Modulation of antioxidant, chelating and antimicrobial activity of poplar chemo-type propolis by extraction procures; LWT - Food Science and Technology. 57: 530-537.

17. Karumi Y, Onyeyili PA, Ogugbuaja VO. 2004. Identification of active principals of Momordica balsamina (Balsam apple) leaf extract. J Med Sci 4: 179-82.

18. Li H B, Wong C C, Cheng K W and Chen F. 2008. Antioxidant properties in vitro and total phenolic contents in methanol extracts from medicinal plants. Food Sci. Technol. 41: 385-390.

19. Marino M, Bersani C and Comi G. 1999. Antimicrobial Actvity of the Essential Oils of Thymus vulgaris L. Measured Using a Bioimpedometric Method. J. Food Protec. 62 (9) : 1017 -1023.

20. Mighri H, Hadjlaoui H, Akrout A, Najjaa H, Neffati M. 2010. Antimicrobial and antioxidant activities of Artemisia herba-alba essential oil cultivated in Tunisian arid zone. CR Chim. 13:380-386.

21. Morreel K, Storme V, Sterck L, Ralph J, Coppieters W, Breyne P, Steenackers M, Georges M, Messens E, Boerjan B .2006. Genetical metabolomics of flavonoid biosynthesis in Populus: a case study, the plant journal; 47, (2) 224-237.

22. Muthu C, Ayyanar M, Raja N, and Ignacimuthu S. 2006. Medicinal plants used by traditional healers in Kancheepuram District of Tamil Nadu, India. Journal of Ethnobiology and Ethnomedicine, 2:43 doi:10.1186/1746-4269-2-43.

23. Oloyede O I. 2005. Chemical profile of unripe pulp of Carica papaya. Pakistan J Nutr 4: 379-81.

24. Oyaizu M. 1986. Studies on products of browning reactions-antioxidative activities of products of browning reaction prepared from glucosamine. Jap J Nutr. 44:307-315.

25. Smith-Palmer A, Stewart J and Fyfe L. 1998. Antimicrobial properties of plant essential oils and essences against five important food-borne pathogens. Lett. In Appl. Microbiol. 26: 118-122.

26. Sokmen A, Gulluce M, Akpulat HA, Tepe B, Sokmen M, Sahin F. 2004. The in vitro antimicrobial and antioxidant activities of the essential oils and methanol extracts of endemic Thymus spathulifolius. Food Control. 15:627-634. 